\title{
Dynamics of Cladocera Community in a Tropical Hypereutrophic Environment (Garças Reservoir, São Paulo, Brazil)
}

\author{
Ariane Carolina Di Genaro, Suzana Sendacz, Munique de Almeida Bispo Moraes, \\ Cacilda Thais Janson Mercante
}

Water Resources Center, Fisheries Institute, São Paulo, Brazil

Email: cthais@pesca.sp.gov.br

Received 8 August 2014; accepted 23 March 2015; published 25 March 2015

Copyright (C) 2015 by authors and Scientific Research Publishing Inc.

This work is licensed under the Creative Commons Attribution International License (CC BY). http://creativecommons.org/licenses/by/4.0/

\section{(c) (i) Open Access}

\begin{abstract}
This study was performed at Garças Reservoir, a hypereutrophic urban lake within São Paulo metropolitan area, Southeast Brazil. This reservoir underwent to a marked limnological change after the harvest of free floating macrophytes, shifting to a hypereutrophic state. Present purposes were to characterize the Cladocera community and verify its association with the water deterioration after the macrophytes removal period as well as to compare it to previous studies, before macrophytes harvesting. Samplings were collected from October 2007 until September 2008 and the results were compared to data obtained during pre-removal period (1997). Principal Component Analysis (PCA) showed that the highest values for water transparency were associated with the macrophytes pre-removal period while the highest values of electrical conductivity, chlorophyll $a$ and total phosphorus were associated with the macrophytes post-removal period, indicating the degradation of the water quality. During this period, large cladocerans disappeared and the small sized species of Bosmina predominated. Male organisms of this genus were found as well as elevated densities of Bosmina huaroensis, suggesting overcrowding. Furthermore, it was detected a reduction of $82 \%$ in the number of species compared to data from 1997 . The shifts to the hypereutrophic state led to aggressive alterations in Cladocera community, suggesting a strong stress on populations.
\end{abstract}

\section{Keywords}

Eutrophycation, Zooplankton, Cladocerans, Bosmina, Tropical Reservoir 


\section{Introduction}

The aquatic macrophytes play an important role in the aquatic ecosystems. They participate in a variety of mechanisms including nutrient competition [1], allelopathic substances [2] and refugia for herbivorous zooplankton [3] [4].

The disappearance of submerged aquatic vegetation in shallow lakes due to eutrophication leads to a turbid state and provokes a dramatic change in the structure of lake biotic community [5]. Dominance of free floating macrophytes is another example of a stable state in shallow ecosystems [6], and a well-known consequence of eutrophication in tropical, subtropical and temperate systems is the outbreak of Eichhornia crassipes [7]-[9].

Long-term studies have been carried out at Garças Reservoir, which is the object of this study. A comprehensive limnological data set collected monthly during 8 years (1997-2004), including periods before and after the harvest of the water hyacinth, demonstrated this ecosystem shifted to a stable degraded state after the macrophytes removal, from eutrophic to hypereutrophic state with permanent cyanobacteria blooms [9] [10].

Despite the increasing knowledge about Garças Reservoir on phytoplankton ecology [11]-[13], algal richness loss in long time series [14], cyanobacteria toxicity [15], trophic state changes [16] [17], and more recently on paleolimnology [18].

The information on zooplankton community is very scarce. The only contribution available in [19] characterized this community in 1997, the macrophytes pre-removal period, and demonstrated the occurrence of trophic conditions indicator species such as rotifers Brachionus angularis, B. calyciflorus, Keratella tecta, the co-occurrence of cyclopoids copepods Thermocyclops decipiens and Metacyclops mendocinus, the calanoid copepods Scolodiaptomus cordeiroi and the cladocerans Daphnia gessneri, Moina micrura and Moina minuta. The role of zooplankton community as indicator of ecological state in biomonitoring programs is well recognized by considering these organisms respond quickly to changes in the water column.

This is the second study about zooplankton community at Garças Reservoir. In this context, the purposes of this study were to characterize the Cladocera community in a hypereutrophic state with permanent cyanobacteria blooms in a shallow tropical reservoir (Garças Reservoir), and compare it with previous study performed during the eutrophic phase (before water hyacinth removal). The results showed how zooplankton behaved in a permanent bloom stage environment and would contribute to the better management of shallow tropical reservoirs.

\section{Material and Methods}

\subsection{Study Area}

Garças Reservoir ( $23^{\circ} 38^{\prime} \mathrm{S}$ and $46^{\circ} 37^{\prime} \mathrm{W}$ ) is located in the reserve of the Parque Estadual das Fontes do Ipiranga (São Paulo, Southeastern Brazil). It is a shallow reservoir, with maximum depth of $4.7 \mathrm{~m}$ and mean depth of 2.1 $\mathrm{m}$, surface area of $88,156 \mathrm{~m}^{2}$, volume of $188,785 \mathrm{~m}^{3}$ and mean theoretical residence time of 71 days [9].

Eutrophication was triggered by the construction of the city zoo (1958) and installation of the São Paulo State Department of Agriculture (1975) within the Garças watershed, increasing loads of untreated sewage from these institutions [18]. These authors inferred that deterioration in water quality began after 1975 and markedly accelerated after $\sim 1990$. Based on a comprehensive data set of eight-year study, reference [9] identified three limnological phases in this environment according to physical, chemical and biological characteristics and considering the water hyacinth cover (Eichhornia crassipes):

Phase I (January 1997-March 1998): water surface coverage with 10\% - 20\% of water hyacinth, presence of cyanobacterial blooms during the spring, high concentrations of chlorophyll $a$ and high values of $\mathrm{pH}$ on water surface.

Phase II (April 1998-August 1999): macrophytes covered 40\% - 70\% of the reservoir water surface. The large macrophyte patches triggered a serious problem with mosquitoes (Mansonia sp.), thus demanding its mechanical removal. This phase was characterized by the harvest of water hyacinth, low algal biomass, and the increase of water transparency and decrease of dissolved oxygen (DO).

Phase III (September 1999-December 2004) was characterized by the drastic reduction of the macrophyte cover on the water surface, along with an abrupt limnological changes such as a significant increase in chlorophyll $a$, cyanobacterial biovolume, total phosphorus (TP) concentrations and $\mathrm{pH}$ values and a drastic decrease in water transparency and DO at the deepest layers of the reservoir. During this phase, the spring cyanobacteria bloom was replaced by permanent multi-specific cyanobacteria blooms, and the reservoir shifted to a hyper- 
trophic state [9] [10].

\subsection{Abiotic and Biotic Variables}

Sampling was carried out on a monthly basis from October 2007 to September 2008. A multiprobe HORIBA U-22 was used for measuring temperature, electrical conductivity (EC) and $\mathrm{pH}$ of the water column vertical profile at five different depths (subsurface, 1, 2, $3 \mathrm{~m}$ and bottom). Water transparency was measured with a Secchi disk. Water samples for determining dissolved oxygen (DO), chlorophyll $a$, total nitrogen (TN), and total phosphorus (TP) were collected at the same five different depths with a van Dorn sampler. The analyses were carried out at the Aquatic Ecology Laboratory of the Instituto de Botânica.

For determining the concentrations of DO, Winkler method was applied as described by [20], TN and TP $(\mu \mathrm{g} / \mathrm{L})$ concentrations were measured according to reference [21], and chlorophyll $a(\mu \mathrm{g} / \mathrm{L})$ concentrations corrected for phaephytin were determined using 90\% ethanol extraction [22]. Further details are available in reference [9].

Zooplankton samples were taken in vertical hauls of the entire water column using a plankton net of $68 \mu \mathrm{m}$ mesh and preserved in $4 \%$ formalin. Qualitative analysis was performed under stereoscopic microscope and the identification of the organisms according to specialized literature [23] [24]. The microcrustaceans were counted in subsamples in an acrylic chamber.

Numerical density of organisms was expressed in numbers of individuals per cubic meter $\left(\mathrm{ind} / \mathrm{m}^{3}\right)$ and the abundance in percentage (number of organisms of a taxon present in a sample relative to the total number of organisms).

Ecological indices such as richness (total number of taxa in a sample), diversity (bits/ind) [25] and evenness [26] were calculated in order to verify changes in biodiversity comparing 1997 with 2007 data.

\subsection{Data Analysis}

The water column mean was calculated per month considering the physical, chemical, and biological variables (water temperature, DO, EC, $\mathrm{pH}, \mathrm{TN}, \mathrm{TP}$ and chlorophyll $a$ ).

Principal Component Analysis (PCA) was performed based on data transformed by ranging and a covariance matrix of the following variables: water transparency, and monthly mean of water temperature, DO, EC, chlorophyll $a$, pH, TN and TP obtained in 1997 and in 2007/2008 (present study). PC-ORD version 4.0 for Windows [27] was used for the analysis.

\section{Results}

During the study period, water transparency remained low, $\mathrm{pH}$ ranged from slightly acid to neutral, electrical conductivity and nutrients concentrations, especially nitrogen and phosphorus were high (Table 1). Thermal stratification occurred in the rainy season (October/2007-March/2008) and more pronounced from December/2007 to February/2008, and the mixing of the water column occurred in April and May/2008, during the dry period (April-September/2008) (Figure 1(a)). Pronounced dissolved oxygen stratification occurred almost over the entire study period, leading to extended periods of oxygen depletion at the bottom layers (Figure 1(b)). Algal biomass (chlorophyll $a$ ) remained high, with annual mean of $119.4 \mu \mathrm{g} / \mathrm{L}$ (Table 1).

The first two axes of principal component analysis (Figure 2) accounted for $70 \%$ of the limnological data variation. The first axis was positively related with water transparency, and negatively related with conductivity, total phosphorus, total nitrogen and chlorophyll (Table 2). In general, it separated the samples of the macrophyte pre-removal period (1997) from the post-removal one (2007/2008), characterized by lower transparency, high nutrients and chlorophyll $a$ concentrations. The second axis separated the sampling units according to the seasonal variation, distinguishing the rainy period from the dry one in both studied periods (1997 and 2007/ 2008). Chlorophyll $a$ and DO were positively related while water temperature was negatively related with this axis (Table 2 and Figure 2).

Cladocera was represented by five species: Bosmina freyi, Bosmina huaroensis, Daphnia ambigua, Diaphanosoma birgei and Moina minuta. Bosmina spp. represented 95\% of total Cladocera, with dominance of Bosmina huaroensis (52\%) followed by juveniles from Bosmina (36\%), Bosmina freyi (5\%) and males (2\%). Diaphanosoma birgei represented $5 \%$ of total Cladocera and Daphnia ambigua and Moina minuta registered the lowest 
Table 1. Mean values of water column and annual minimum, maximum, mean and standard deviation of limnological variables at Garças Reservoir from October 2007 to September 2008.

\begin{tabular}{|c|c|c|c|c|c|c|c|c|}
\hline \multirow{2}{*}{ Months } & \multicolumn{8}{|c|}{ Variables } \\
\hline & $\mathrm{SD}(\mathrm{m})$ & $\mathrm{T}\left({ }^{\circ} \mathrm{C}\right)$ & DO (mg/L) & $\mathrm{pH}$ & $\mathrm{EC}(\mu \mathrm{S} / \mathrm{cm})$ & $\mathrm{TN}(\mu \mathrm{g} / \mathrm{L})$ & $\mathrm{TP}(\mu \mathrm{g} / \mathrm{L})$ & Chlor $a(\mu \mathrm{g} / \mathrm{L})$ \\
\hline Oct/07 & 0.19 & 19.6 & 3.4 & 7.2 & 351.6 & 4310.3 & 278.2 & 154.5 \\
\hline Nov/07 & 0.18 & 20.6 & 6.2 & 7.9 & 301.6 & 3612.6 & 264.2 & 198.7 \\
\hline Dec/07 & 0.20 & 22.4 & 0.4 & 6.1 & 457.2 & 6194.0 & 282.3 & 52.7 \\
\hline Jan/08 & 0.30 & 21.7 & 1.7 & 6.8 & 346.2 & 5073.3 & 290.0 & 76.8 \\
\hline Feb/08 & 0.26 & 23.2 & 3.4 & 7.2 & 340.2 & 1951.8 & 292.6 & 72.0 \\
\hline Mar/08 & 0.30 & 21.9 & 3.0 & 6.5 & 258.8 & 2226.9 & 225.9 & 133.7 \\
\hline Apr/08 & 0.30 & 21.4 & 3.1 & 6.9 & 294.8 & 6772.0 & 110.8 & 132.4 \\
\hline May/08 & 0.30 & 17.9 & 5.7 & 5.1 & 273.4 & 4847.0 & 143.5 & 149.4 \\
\hline Jun/08 & 0.23 & 18.1 & 4.0 & 6.4 & 164.8 & 5078.4 & 146.2 & 99.8 \\
\hline $\mathrm{Jul} / 08$ & 0.25 & 17.5 & 4.5 & 7.2 & 194.0 & 3805.8 & 130.4 & 69.8 \\
\hline Aug/08 & 0.22 & 18.6 & 4.3 & 7.5 & 190.0 & 3011.6 & 109.8 & 101.1 \\
\hline Sep/08 & 0.30 & 18.3 & 7.4 & 7.4 & 212.0 & 195.2 & 285.7 & 191.8 \\
\hline Annual mean & 0.25 & 20.1 & 3.9 & 6.9 & 282.1 & 3923.2 & 213.3 & 119.4 \\
\hline Standard deviation & 0.05 & 2.0 & 1.9 & 0.8 & 84.8 & 1871.7 & 77.8 & 48.4 \\
\hline Minimum & 0.18 & 17.5 & 0.4 & 5.1 & 164.8 & 195.2 & 109.8 & 52.7 \\
\hline Maximum & 0.30 & 23.2 & 7.4 & 7.9 & 457.2 & 6772.0 & 292.6 & 198.7 \\
\hline
\end{tabular}

$\mathrm{SD}=$ Secchi depth; $\mathrm{T}=$ Water temperature; $\mathrm{DO}=$ Dissolved oxygen; $\mathrm{EC}=$ Electrical conductivity; $\mathrm{TN}=$ Total nitrogen; $\mathrm{TP}=$ Total phosphorus; Chlor $a=$ Chlorophyll $a$.

Table 2. Loadings of limnological variables on the first two principal components and the proportion of variance explained by each component of PCA in 1997 and 2007/2008.

\begin{tabular}{|c|c|c|}
\hline \multirow{2}{*}{ Variables } & \multicolumn{2}{|c|}{ Main Components } \\
\hline & Axis 1 & Axis 2 \\
\hline Secchi depth & 0.759 & -0.281 \\
\hline Water temperature & -0.293 & -0.756 \\
\hline Dissolved oxygen & 0.220 & 0.843 \\
\hline Electrical conductivity & -0.919 & -0.144 \\
\hline Chlorophyll $a$ & -0.590 & 0.665 \\
\hline Total nitrogen & -0.630 & -0.392 \\
\hline Total phosphorus & -0.911 & 0.155 \\
\hline $\mathrm{pH}$ & 0.023 & 0.023 \\
\hline Explained variation & $45 \%$ & $25 \%$ \\
\hline
\end{tabular}

abundance (Figure 3(b)). In 1997, Daphnia gessneri dominated this group considering relative abundance (Figure 3(a)).

The highest numerical density of community occurred in October/2007 (1,226,800 ind $\left./ \mathrm{m}^{3}\right)$, and the lowest in December/2007 (159 ind $\left./ \mathrm{m}^{3}\right)$. Compared to 1997, the highest densities occurred during the macrophytes postremoval period (Figure 4).

In 199728 taxa were registered while in 2007/2008 only five taxa were registered. Species richness and diversity were markedly higher in 1997, and evenness was slightly higher in 2007/2008 (Figure 5). 

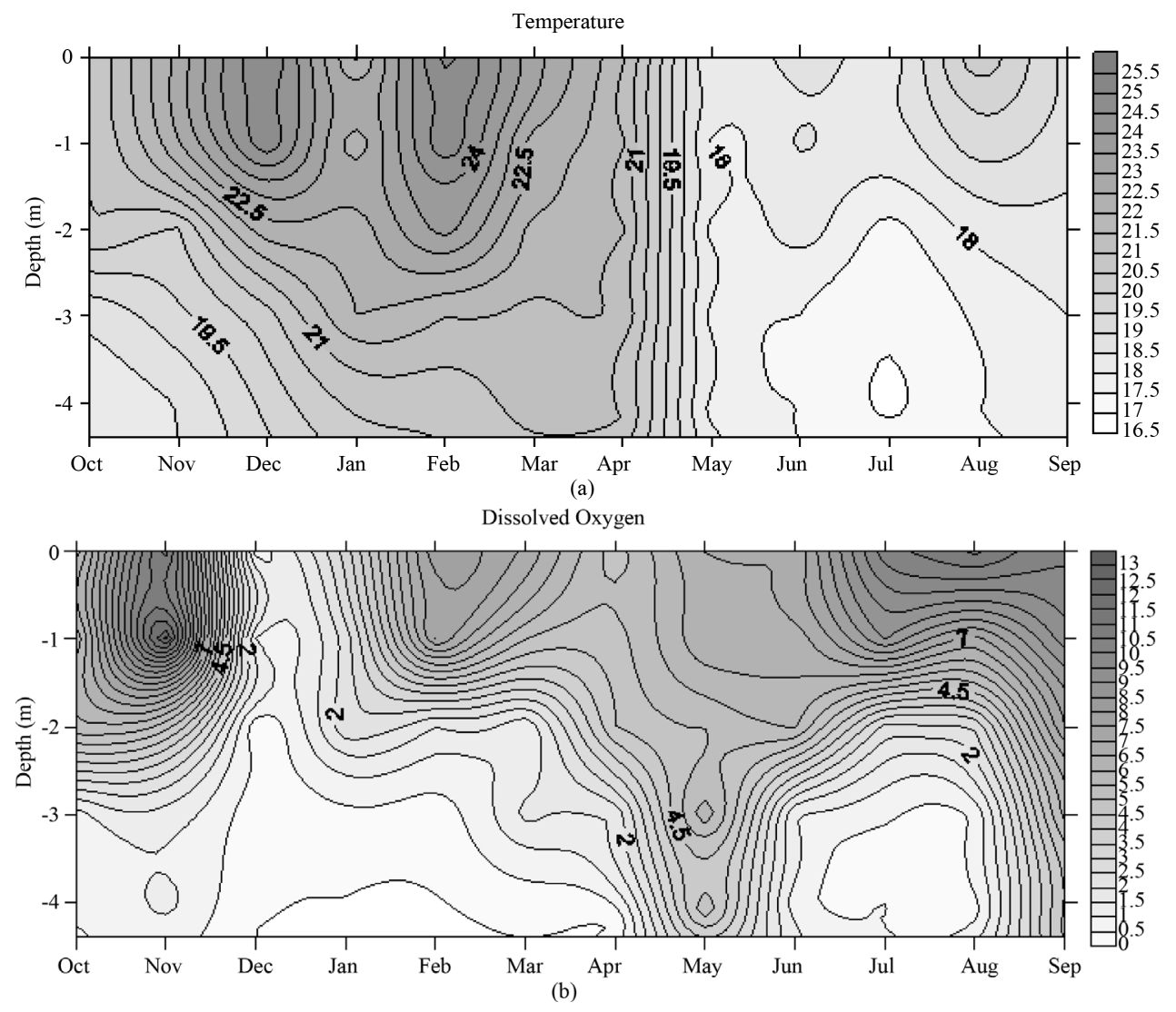

Figure 1. Depth-time diagram of (a) water temperature and (b) dissolved oxygen at Garças Reservoir from October 2007 to September 2008.

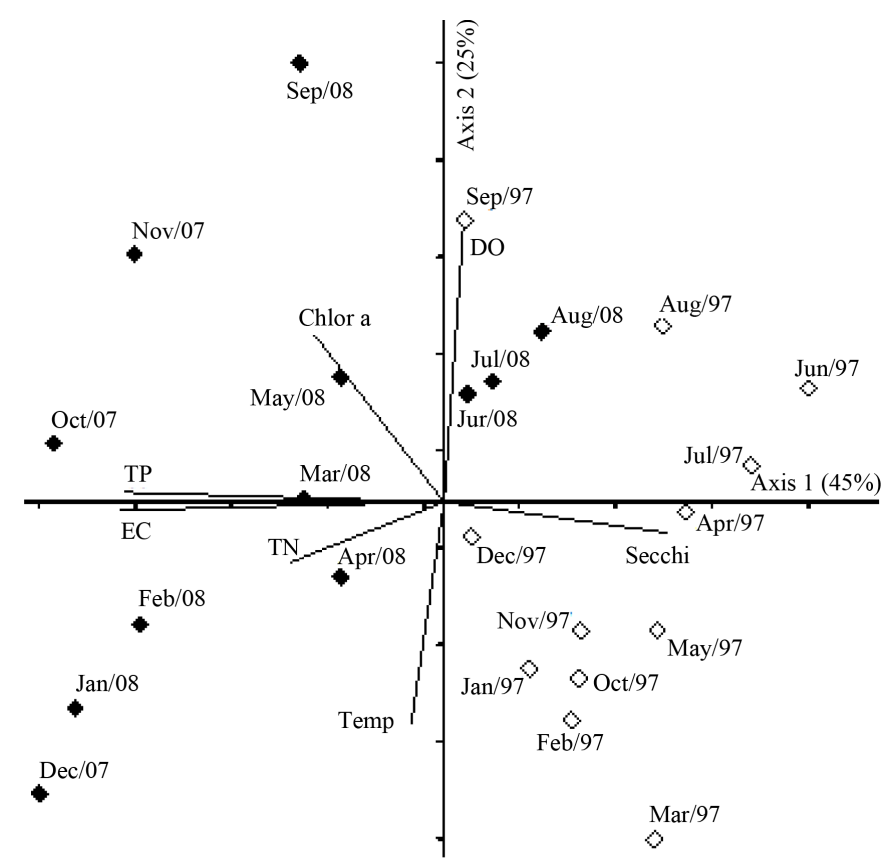

Figure 2. PCA ordination of limnological variables at Garças Reservoir in 1997 and 2007/2008. Abbreviations: Secchi: Secchi depth; Temp: Water Temperature; DO: Dissolved oxygen; EC: Electrical conductivity; TN: Total nitrogen; TP: Total phosphorus; Chlor $a$ : Chlorophyll $a$. 


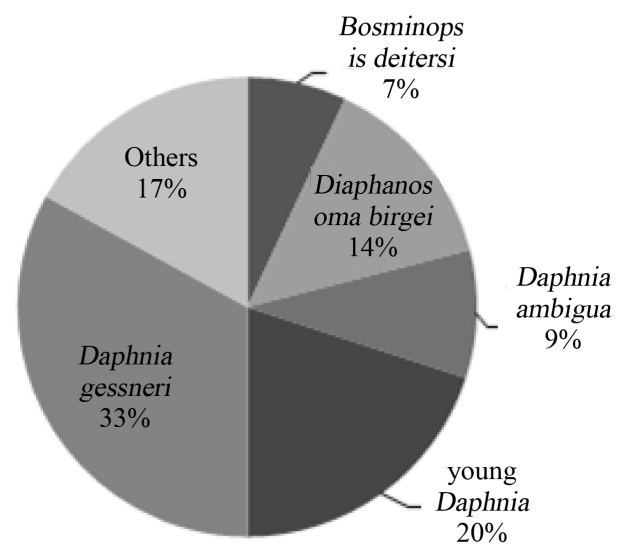

(a)

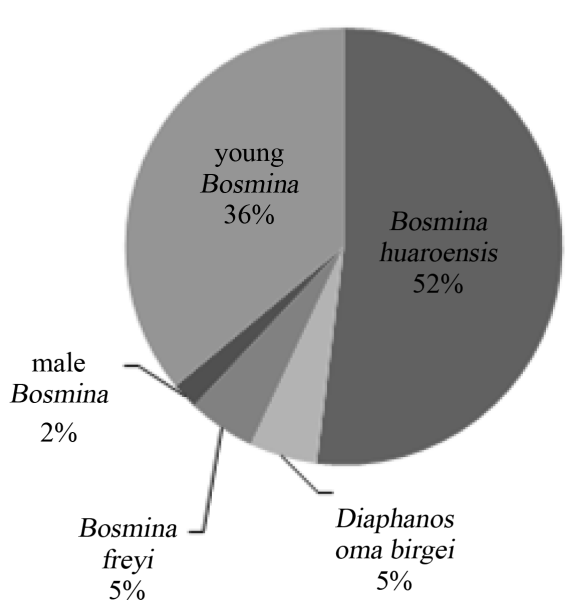

(b)

Figure 3. Relative abundance (\%) of Cladocera community at Garças Reservoir in (a) 1997 [19] and (b) $2007 / 2008$.

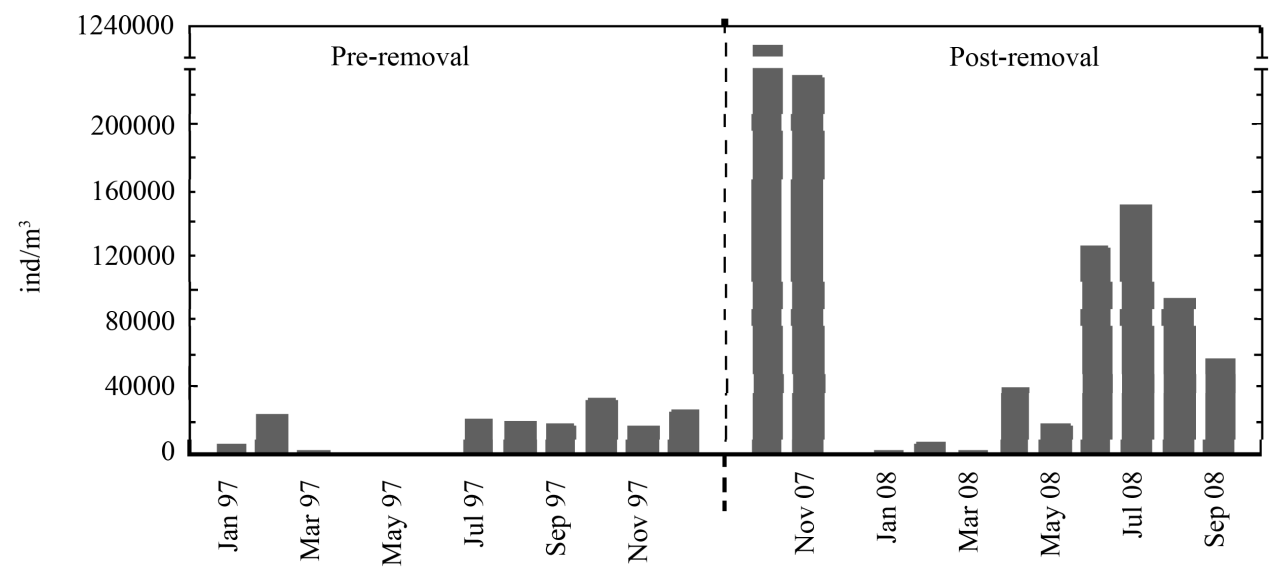

Figure 4. Numerical densities (ind $/ \mathrm{m}^{3}$ ) of Cladocera community at Garças Reservoir during macrophytes pre- (1997 [19]) and post-removal (2007/2008) periods.

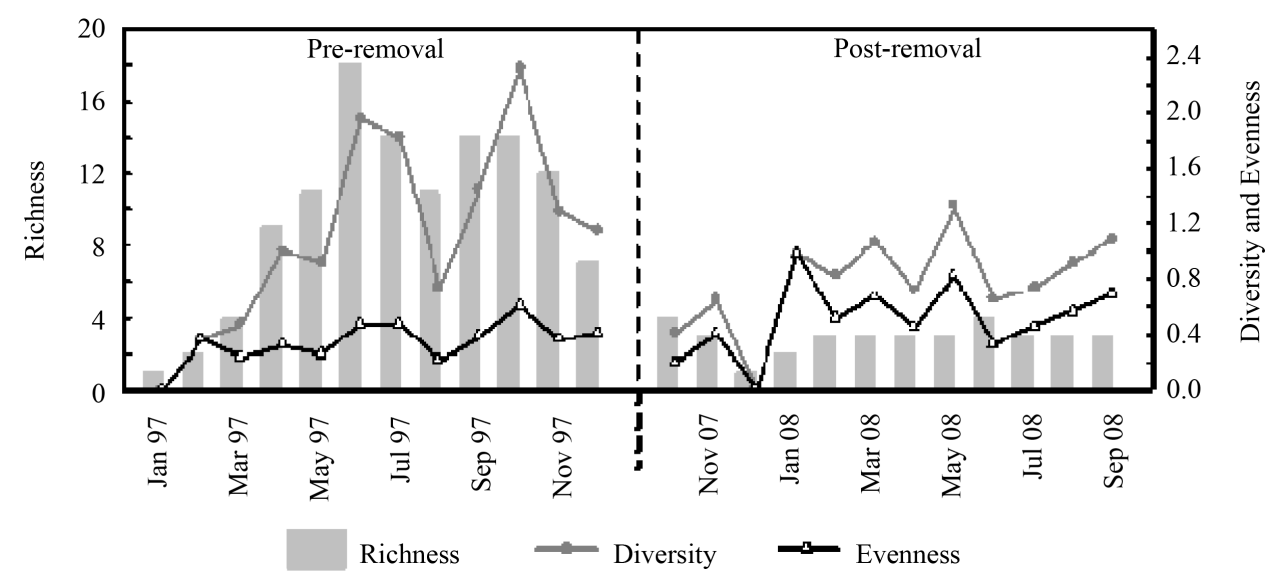

Figure 5. Richness, Shannon diversity (bit/ind) and evenness of Cladocera community at Garças Reservoir during macrophytes pre- (1997 [19]) and post-removal (2007/2008) periods. 
During the latter period, three species were numerically relevant. Bosmina huaroensis was dominant in October and November 2007 and August 2008. After registering the highest densities in October and November (706,692 and 134,302 ind $/ \mathrm{m}^{3}$, respectively), this species disappeared during the following two months (December 2007 and January 2008) and re-appeared in February 2008 in dramatically lower densities $\left(108 \mathrm{ind} / \mathrm{m}^{3}\right)$.

Bosmina freyi was present all along this study and dominated the community in February and April 2008. Bosmina young individuals were registered the whole studied period and were dominant in December 2007, June and July 2008. Male individuals were observed in October and November 2007 and in June, July, August and September 2008. High density of male organisms occurred in the first month of this study $\left(32,664 \mathrm{ind} / \mathrm{m}^{3}\right)$.

Diaphanosoma birgei was the third more relevant species of Cladocera and was absent in December 2007 and January 2008. Nevertheless, it was the dominant Cladocera species in May and September 2008 (dry season). Moina minuta was dominant over other Cladocera species in January 2008, reaching $631 \mathrm{ind} / \mathrm{m}^{3}$.

\section{Discussion}

The anoxic conditions observed in the deepest layers were propitious to the release of phosphorus by sediment (via feedback mechanisms), thus accelerating the eutrophication process as discussed in previous studies by [9] [17]. According to these authors, anoxic conditions were persistent after the macrophyte removal, and phosphorus dynamics, initially driven by allochthonous loads, was replaced by internal (autochthonous) ecological processes.

In this period when the high values of TP were detected, it was also observed low richness of the Cladocera community at Garças reservoir. Reference [28] showed that zooplankton species richness declined considerably with increasing total phosphorus concentration on Danish lakes. The decline was particularly noticeable for the number of cladoceran species. Reference [29] also found Cladocera assemblage changes with trophic state mainly due to total phosphorus concentration.

In Garças reservoir, only three species were common to the pre-removal (1997 [19]) and post-removal periods (2007/2008): Daphnia ambigua, Diaphanosoma birgei and Moina minuta.

Comparing 1997 with 2007/2008, twenty-five cladocerans species disappeared (Alona guttata, A. monocantha, Alona sp., Biapertura spp., Bosmina hagmanni, B. tubicen, Bosmina sp., Bosminopsis deitersi, Camptocercus daday, Ceriodaphnia cornuta cornuta, C. cornuta rigaudi, C. cf. reticulata, Chydorus pubecens, C. sphaericus, Chydorus sp., Daphnia gessneri, Daphnia sp., Diaphanosoma sp., Disparalona daday, Ilyocryptus spnifer, Macrothrix spinosa, Macrothrix sp., Moina micrura, Moina sp. and Simocephalus sp.). The disappearance of nonplanktonic species can be attributed to the macrophytes removal because these organisms use these plants as refuge and food source.

The dense cyanobacterial blooms recorded continuously at Garças Reservoir [9] [10] probably led to the replacement of large cladocerans, like Daphnia gessneri, predominant species in 1997 [19], for small cladocerans, like Bosmina huaroensis, predominant in this study.

Other studies also found decrease in contribution of Daphnia spp. to the total biomass of cladocerans with increasing total phosphorus concentration [28]. Replacement of Daphnia spp. for Bosmina huaroensis was also reported in a hypereutrophic lake in Argentina, Don Tomás Lake [30].

In eutrophic lakes, large cladocerans (e.g. Daphnia) may disappear from the environment or be replaced by smaller organisms such as small cladocerans, rotifers and copepods due to the deterioration of water quality and cyanobacterial blooms [30]-[34]. Large cladocerans are impaired in water bodies dominated by cyanobacteria, among other factors for having a large carapace opening which allows the entry of cyanobacterial filaments and colonies in the filtering chamber, thus favoring the mechanical or chemical inhibition of the thoracic appendages movements by toxins. The reduction of the filtration rate mitigates the energy for growth and reproduction as a consequence. In smaller species of cladocerans, the carapace opening is too small for filaments and colonies to enter [35] what makes them less susceptible to the harmful effects of cyanobacteria.

Another reason for the successful presence of Bosmina in this environment is its dual-mode feeding which combines raptorial and filter-feeding that allows them to distinguish cyanobacteria from other particles. Besides the resistance to the harmful effects of cyanobacterial blooms, Bosmina can feed from bacteria and detritus [36]. This fact can explain their occurrence and predominance in eutrophic reservoirs.

By comparing the mean density of Cladocera at the macrophytes pre-removal period (13,395 ind $/ \mathrm{m}^{3}$ [19]) and post-removal period, an increase of approximately $1000 \%$ occurred in 2007/2008 $\left(162,357 \mathrm{ind} / \mathrm{m}^{3}\right)$. This oc- 
curred due to the Bosmina huaroensis overcrowding in October and November 2007, when high densities of males of this genus were registered.

The reproductive strategies of cladocerans facilitate the development of large transitory population. These organisms are typically reproduced by asexual reproduction (parthenogenesis); however, environmental factors may induce sexual reproduction and production of resting eggs which allow the survival of the species during periods of harsh environmental conditions [37].

The resting eggs and male production are uncommon or unknown in some Cladocera species. It is generally related to adverse conditions such as changes in water temperature, overcrowding, that results in reduction of food supply, excretion products accumulation [38], decreasing of ingestion rate [39] and other factors probably still unknown.

Bosmina huaroensis disappeared for two subsequent months right after the period of overcrowding and appeared again in February 2008. The absence of male organisms was observed for six months until June 2008 when they were noticed again. It was detected harsh environmental conditions during the two-month period of $B$. huaroensis absence (December and January).

The disappearance of Bosmina huaroensis and of the male population, in addition to the low densities of cladocerans recorded in December may be associated with the phytoplankton collapse, followed by toxins release and the consequent high mortality rates of these organisms. Another factor resulting from the collapse, which might have harmed the zooplankton, is the low dissolved oxygen concentration throughout the highly stratified water column in December.

Changes in diversity and species richness were also detected. In 1997, the low diversity and evenness had already evidenced the predominance of few species, a typical condition of impacted environments. However, the reduction of $82 \%$ in richness value and the decrease of diversity values are indicative that changes have further restricted the environment to most adaptable species.

Although the evenness values did not present major changes, it should be considered that the number of species decreased significantly. Therefore the distribution of the relative abundances of species was more uniform when compared to the pre-removal period, which presented many species but few dominant and many rare ones.

Reference [40] investigated the relation between primary productivity and richness of species in lake communities (phytoplankton, rotifers, cladocerans, copepods, macrophytes and fish) and verified that the strongest and most consistent relation was the decline in richness of the crustacean zooplankton species with increased productivity. The variety of mechanisms that interfere in the relation richness-productivity includes the transient dynamics and the shift to a new system state as noticed at Garças Reservoir.

The free floating macrophytes removal in shallow systems may cause disastrous effects to the ecosystem as well as to biotic communities, as observed in this study for Cladocera. The deterioration of water quality after the hyper eutrophication triggered by the harvest of macrophytes promoted the reduction of species richness and diversity, changes in composition and structure of community with replacement of Daphnia by smaller cladocerans, signs of population stress with occurrence of male organisms and overcrowding.

\section{Conclusion}

We believe this study provides relevant information for the study of Cladocera as bioindicators of water quality and on the dynamics of these organisms in hypereutrophic tropical reservoirs, since it presents and discusses the data scarcely found in literature, like the occurrence of male organisms and overcrowding. Present results may contribute to further monitoring of zooplankton community as a tool to assess aquatic ecosystem with anthropogenic influences in tropical/subtropical areas.

\section{Acknowledgements}

We thank Dr. Denise de Campos Bicudo for the valuable theoretical contribution and revision of the manuscript and Dr. Sandra Costa Vieira and the Aquatic Ecology Laboratory of the Instituto de Botânica for providing necessary data for this study.

\section{References}

[1] Van Donk, E., Grimm, M.P., Gulati, R.D. and Klein Breteler, J.P.G. (1990) Whole-Lake Food Web Manipulation as a 
Means to Study Community Interactions in a Small Ecosystem. Hydrobiologia, 200-201, 275-289. http://dx.doi.org/10.1007/BF02530346

[2] Wium-Andersen, S. (1987) Allelopathy among Aquatic Plants. Archiv für Hydrobiologie, Beiheft Ergebnisse der Limnologie, 27, 167-172.

[3] Timms, R.M. and Moss, B. (1984) Prevention of Growth of Potentially Dense Phytoplankton Populations by Zooplankton Grazing, in the Presence of Zooplantivorous Fish, in a Shallow Wetland Ecosystem. Limnology and Oceanography, 29, 472-486. http://dx.doi.org/10.4319/lo.1984.29.3.0472

[4] Schriver, P., Bogestrand, J., Jeppesen, E. and Sondergaard, M. (1995) Impact of Submerged Macrophytes on Fish-Zooplankton Phytoplankton Interactions: Large-Scale Enclosure Experiments in a Shallow Eutrophic Lake. Freshwater Biology, 33, 255-270. http://dx.doi.org/10.1111/j.1365-2427.1995.tb01166.x

[5] Scheffer, M. (2001) Alternative Attractors of Shallow Lakes. The Scientific World Journal, 1, 254-263. http://dx.doi.org/10.1100/tsw.2001.62

[6] Scheffer, M., Szabo, S., Gragnani, A., Van Nes, E.H., Rinaldi, S., Kautsky, N., Norberg, J., Roijackers, R.M.M. and Franken, R.J.M. (2003) Floating Plant Dominance as a Stable State. Proceedings of the National Academic of Sciences of the United States of America, 100, 4040-4045. http://dx.doi.org/10.1073/pnas.0737918100

[7] Rommens, W., Maes, J., Dekeza, N., Inghelbrecht, P., Nhiwatiwa, T., Holsters, E., Ollevier, F., Marshall, B. and Brendonck, L. (2003) The Impact of Water Hyacinth (Eichhornia crassipes) in a Eutrophic Subtropical Impoundment (Lake Chivero, Zimbabwe). I. Water Quality. Archiv für Hydrobiologie, 158, 373-388. http://dx.doi.org/10.1127/0003-9136/2003/0158-0373

[8] Wilson, J.R., Holst, N. and Rees, M. (2005) Determinants and Patterns of Population Growth in Water Hyacinth. Aquatic Botany, 81, 51-67. http://dx.doi.org/10.1016/j.aquabot.2004.11.002

[9] Bicudo, D.C., Fonseca, B.M., Bini, L.M., Crossetti, L.O., Bicudo, C.E.M. and Araújo-Jesus, T. (2007) Undesirable Side Effects of Water Hyacinth Control in a Shallow Tropical Reservoir. Freshwater Biology, 52, 1120-1133. http://dx.doi.org/10.1111/j.1365-2427.2007.01738.x

[10] Crossetti, L.O. and Bicudo, C.E.M. (2008) Adaptations in Phytoplankton Life Strategies to Imposed Change in a Shallow Urban Tropical Eutrophic Reservoir, Garças Reservoir, Over 8 Years. Hydrobiologia, 614, 91-105. http://dx.doi.org/10.1007/s10750-008-9539-1

[11] Tucci, A., Sant’Anna, C.L., Gentil, C.G. and Azevedo, M.T.P. (2006) Phytoplankton of Garças Lake, São Paulo, Brazil: A Eutrophic Urban Reservoir. Hoehnea, 33, 147-175 (in Portuguese).

[12] Ramírez, J.J. and Bicudo, C.E.M. (2005) Diurnal and Spatial (Vertical) Dynamics of Nutrients (N, P, Si) in Four Sampling Days (Summer, Fall, Winter, and Spring) in a Tropical Shallow Reservoir and Their Relationships with the Phytoplankton Community. Brazilian Journal of Biology, 65, 141-157. http://dx.doi.org/10.1590/S1519-69842005000100018

[13] Fonseca, B.M. and Bicudo, C.E.M. (2008) Phytoplankton Seasonal Variation in a Shallow Stratified Eutrophic Reservoir (Garças Pond, Brazil). Hydrobiologia, 600, 267-282. http://dx.doi.org/10.1007/s10750-007-9240-9

[14] Crossetti, L.O., Bicudo, D.C., Bicudo, C.E.M and Bini, L.M. (2008) Phytoplankton Biodiversity Changes in a Shallow Tropical Reservoir during the Hypertrophication Process. Brazilian Journal of Biology, 68, 1061-1067. http://dx.doi.org/10.1590/S1519-69842008000500013

[15] Sant'Anna, C.L. and Azevedo, M.T.P. (2000) Contribution to the Knowledge of Potentially Toxic Cyanobacteria from Brazil. Nova Hedwigia, 71, 359-385.

[16] Mercante, C.T.J. and Tucci-Moura, A. (1999) Comparison between the Indices of Carlson and Carlson Modified Applied to Two Sub-Tropical Aquatic Environments, São Paulo, SP. Acta Limnologica Brasiliensia, 11, 1-4 (in Portuguese).

[17] Bicudo, D.C., Fonseca, B.M., Bicudo, C.E.M, Bini, L.M. and Araújo-Jesus, T. (2006) Removal of Eichhornia crassipes in a Shallow Tropical Reservoir and Its Implications for Trophic Classification System: Long-Term Study in the Garças Lake, São Paulo, Brazil. In: Tundisi, J.G., Matsumura-Tundisi, T. and Sidagis-Galli, C.V., Eds., Eutrophication in South America: Causes, Consequences and Management and Control Technologies, Author’s Edition, São Carlos, 471-501 (in Portuguese).

[18] Costa-Boddeker, S., Bennion, H., Jesus, T.A., Albuquerque, A.L.S., Figueira, R.C.L. and Bicudo, D.C. (2012) Paleolimnological Inferred Eutrophication of a Shallow, Tropical, Urban Reservoir in Southeast Brazil. Journal of Paleolimnology, 48, 751-766. http://dx.doi.org/10.1007/s10933-012-9642-1

[19] Piva-Bertoletti, S.A.E. (2001) Zooplankton in Lakes of the Parque Estadual das Fontes do Ipiranga (SP) and Relations between Zooplankton Species and Trophic Status in Water Bodies of the São Paulo State. Ph.D. Thesis, São Paulo University, São Paulo (in Portuguese).

[20] Golterman, H.L., Clymo, R.S. and Ohmstad, M.A.M. (1978) Methods for Chemical Analysis of Freshwaters. Blackwell Scientific Publications, Oxford. 
[21] Valderrama, J.C. (1981) The Simultaneous Analysis of Total Nitrogen and Total Phosphorous in Natural Waters. Marine Chemistry, 10, 109-122. http://dx.doi.org/10.1016/0304-4203(81)90027-X

[22] Sartory, D.P. and Grobbelaar, J.U. (1984) Extraction of Chlorophyll $a$ from Freshwater Phytoplankton for Spectrophotometric Analysis. Hydrobiologia, 114, 177-187. http://dx.doi.org/10.1007/BF00031869

[23] Elmoor-Loureiro, L.M.A. (1997) Identification Manual of Cladocerans Limnic of Brazil. Universa, Brasília (in Portuguese).

[24] Elmoor-Loureiro, L.M.A., Mendonça-Galvão, L. and Padovesi-Fonseca, C. (2004) New Cladocerans Records from Lake Paranoá, Central Brazil. Brazilian Journal of Biology, 63, 415-422.http://dx.doi.org/10.1590/S1519-69842004000300006

[25] Shannon, C.E. and Weaver, W. (1949) The Mathematical Theory of Communication. University of Illinois Press, Champaign.

[26] Pielou, E.C. (1975) Ecological Diversity. Wiley-Interscience, New York.

[27] McCune, B. and Mefford, M.L. (1999) PC-ORD. Multivariate Analysis of Ecological Data, Version 4. MJM Software Design, Gleneden Beach.

[28] Jeppesen, E., Nõges, P., Davidson, T.A., Haberman, J., Nõges, T., Blank, K., Lauridsen, T.L., Søndergaard, M., Sayer, C., Laugaste, R., Johansson, L.S., Bjerring, R. and Amsinck, S.L. (2011) Zooplankton as Indicators in Lakes: A Scientific-Based Plea for Including Zooplankton in the Ecological Quality Assessment of Lakes According to the European Water Framework Directive (WFD). Hydrobiologia, 676, 279-297. http://dx.doi.org/10.1007/s10750-011-0831-0

[29] Jensen, T.C., Dimante-Deimantovica, I., Schartau, A.K. and Walseng, B. (2012) Cladocerans Respond to Differences in Trophic State in Deeper Nutrient Poor Lakes from Southern Norway. Hydrobiologia, 715, 101-112. http://dx.doi.org/10.1007/s10750-012-1413-5

[30] Echaniz, S.A., Vignatti, A.M. and Bunino, P.C. (2008) The Zooplankton of a Shallow Hypertrophic Lake of Central Argentina: Changes after a Decade. Biota Neotropica, 8, 63-71 (in Spanish). http://dx.doi.org/10.1590/S1676-06032008000400005

[31] Edmondson, W.T. and Litt, A.H. (1982) Daphnia in Lake Washington. Limnology and Oceanography, 27, $272-293$. http://dx.doi.org/10.4319/lo.1982.27.2.0272

[32] Gasiūnaite, Z.R. and Olenina, I. (1997) Zooplankton-Phytoplankton Interactions: A Possible Explanation of the Seasonal Succession in the Kuršių Marios Lagoon. Hydrobiologia, 363, 333-339. http://dx.doi.org/10.1023/A:1003161319026

[33] Pinto-Coelho, R.M., Bezerra-Neto, J.F., Giani, A., Macedo, C.F., Figueredo, C.C. and Carvalho, E.A. (2003) The Collapse of a Daphnia laevis (Birge, 1878) Population in Pampulha Reservoir, Brazil. Acta Limnologica Brasiliensia, 15, 53-70.

[34] Deng, D.G., Xie, P., Zhou, Q., Yang, H., Guo, L.G. and Geng, H. (2008) Field and Experimental Studies on the Combined Impacts of Cyanobacterial Blooms and Small Algae on Crustacean Zooplankton in a Large, Eutrophic, Subtropical, Chinese Lake. Limnology, 9, 1-11. http://dx.doi.org/10.1007/s10201-007-0229-x

[35] Degans, H. and De Meester, L. (2002) Top-Down Control of Natural Phyto- and Bacterioplankton Prey Communities by Daphnia magna and by the Natural Zooplankton Community of the Hypereutrophic Lake Blankaart. Hydrobiologia, 479, 39-49. http://dx.doi.org/10.1023/A:1021002128426

[36] DeMott, W.R. and Kerfoot, W.C. (1982) Competition among Cladocerans: Nature of the Interaction between Bosmina and Daphnia. Ecology, 63, 1949-1966. http://dx.doi.org/10.2307/1940132

[37] Ślusarczyk, M. (1998) Diapause as a Survival Strategy. Wiadomosci Ekologiczne, 44, 279-303 (in Polish).

[38] Melão, M.G.G. (1999) Development and Reproductive Aspects of Cladocerans and Copepods of Brazilian Continental Waters. In: Pompêo, M.L.M., Ed., Perspectives on Brazil Limnology, Gráfica e Editora União, São Luís, 1-13 (in Portuguese).

[39] Gilbert, J.J. and Williamson, C.E. (1983) Sexual Dimorphism in Zooplankton (Copepoda, Cladocera, and Rotifiera). The Annual Review of Ecology, Evolution, and Systematics, 14, 1-33. http://dx.doi.org/10.1146/annurev.es.14.110183.000245

[40] Dodson, S., Arnott, S.E. and Cottigham, K.L. (2000) The Relationship in Lake Communities between Primary Productivity and Species Richness. Ecology, 81, 2662-2679. http://dx.doi.org/10.1890/0012-9658(2000)081[2662:trilcb]2.0.co;2 